\title{
Mixed Court and Jury Court: Could the Continental Alternative Fill the American Need?
}

\author{
John H. Langbein
}

\begin{abstract}
For cases of serious crime a number of European countries employ a variant of the jury called the mixed court, in which laymen and professional judges sit together in a single panel that deliberates and decides on all issues of verdict and sentence. Trials in the mixed court proceed quite rapidly, in large measure because the mixed court dispenses with most of the time-consuming practices of jury control that characterize Anglo-American trial procedure. Consequently, the legal system can process all cases of serious crime to full trial. The present article describes the German mixed-court system and contrasts it with the American jury, asking to what extent the mixed court serves the purposes of the jury. The conclusion is that the mixed court serves the jury policies well, though not fully; and that it is a superior alternative to the indigenous nontrial devices-plea bargaining and bench trial-that have displaced the jury from routine American practice.
\end{abstract}

In the nineteenth century a number of European countries set out to emulate the Anglo-American criminal jury system. After much experimentation, especially in the German states, there emerged from this process of reception and adaptation the "mixed court" of lay and professional judges, which has become the prevalent form of court structure for cases of serious crime in modern Europe. ${ }^{1}$ Professional judges join with juror-like lay judges to form a trial panel that deliberates and decides collectively on all issues of guilt determination (which we shall hereafter call verdict) and sentence.

The mixed court shares with the jury court the idea that the participa-

John H. Langbein is Max Pam Professor of American and Foreign Law, University of Chicago Law School, and Affiliated Scholar, American Bar Foundation.

The author wishes to thank Joachim Herrmann for arranging interviews with lay judge selection officers in Germany. References and suggestions from Albert Alschuler, Gerhard Casper, Joachim Herrmann, Spencer Kimball, Thomas Weigend, and Peter Westen, and the research assistance of Joseph Rugg are gratefully acknowledged, as is the financial support of the American Bar Foundation and the Fritz Thyssen Stiftung.

1. For a concise English-language account of the history of the invention of the mixed court in Germany, see Gerhard Casper \& Hans Zeisel, Lay Judges in the German Criminal Courts, 1 J. Legal Stud. 135, 136-41 (1972) [hereinafter cited as Casper \& Zeisel]. Figures on the modern extent of the mixed court in Western European legal systems are tabulated in Gerhard Casper \& Hans Zeisel, Der Laienrichter im Strafprozess 9 (Heidelberg: C. F. Müller Juristischer Verlag, 1979 [hereinafter cited as Casper \& Zeisel, Laienrichter]. 
tion of nonprofessionals in criminal adjudication is a value of fundamental importance. However, the mixed court injects lay participation in a fashion that greatly accelerates trial procedure by comparison with the jury court, because the mixed court dispenses with our familiar trappings of jury control.

As the Anglo-American jury system has grown ever more cumbersome, it has fallen ever more into disuse (a phenomenon discussed further in part II of this article). Thoughtful observers have begun to wonder whether the mixed court-the Continental offshoot of our jury systemmight become an object of emulation for us. In 1977 the then president of the American Bar Association noticed that the recent Supreme Court cases on jury size might "permit experimentation with combinations of laymen and professional judges, such as the mixed courts that accelerate the procedure in criminal matters in a number of Continental countries." 2

This article takes the German version of the mixed-court system as the subject of comparative study. German experience with mixed courts has been the longest and most varied, and the German system has attracted a significant scholarly literature. ${ }^{3}$ My immediate object is to explore a fundamental question that arises when Americans attempt to evaluate the mixed court from the perspective of the common law tradition: To what

2. Justin A. Stanley, The Resolution of Minor Disputes and the Seventh Amendment, 60 Marquette L. Rev. 963, 971 (1977). (Stanley's context was the reform of American small claims courts, an exceptionally adventurous borrowing from the criminal procedural context of the mixed court.)

There are faint stirrings in the direction of a mixed court in England. See Antony Allott, A Special Crown Court: Overcoming the Law's Delays, 143 Justice of the Peace 707 (1979), proposing a court composed of "a professional judge or magistrate sitting with two lay magistrates." ("Magistrates" in this usage are the citizens, predominantly nonlawyers, who serve as justices of the peace.) A similar thought has been attributed to the Lord Chancellor, whom the Economist describes as "considering offering defendants a 'lay magistrate plus judge' option instead [of jury trial]." Juries: Held in Contempt, Economist, Mar. 8, 1980, at 69. Some years ago Glanville Williams pointed to the example of the mixed court in arguing for the extension of jury authority to matters of sentence. Glanville Williams, The Proof of Guilt 299-304 (2d ed. London: Stevens \& Sons, Ltd., 1958). See also J. A. Andrews, Uses and Misuses of the Jury, in Reshaping the Criminal Law: Essays in Honour of Glanville Williams 37, 56 (P. R. Glazebrook, ed.) (London: Stevens \& Sons, Ltd., 1978).

The state of Vermont employs a pair of laymen as "assistant judges" in a variety of matters, civil and criminal. However, in cases of serious crime the assistant and professional judges are conceived of as the "bench" that presides and sentences, while a separate and conventional jury performs the customary trial function. Recently, the state supreme court ruled in a first-degree murder case that to continue to allow these lay judges to participate in determining questions of law violated due process. State v. Dunkerley, 365 A.2d 131 (1976). See generally on the use of laymen in lower judicial office, Linda Silberman, Non-Attorney Justice in the United States: An Empirical Study (New York: Institute of Judicial Administration, 1979).

3. In addition to the works by Casper \& Zeisel, supra note 1, see Hans-Heinrich Jescheck, Das Laienrichtertum in der Strafrechtspflege der Bundesrepublik Deutschland und der Schweiz, 94 Schweizerische Zeitschrift für Strafrecht 229 (1977), and modern literature there cited. For older work see the two-volume set of studies, Schwurgerichte and Schöffengerichte (Wolfgang Mittermaier \& M. Liepmann, eds.) (Leipzig, 1908). A forthcoming book is John P. Richert, The Role of Lay Judges in the West German Criminal Courts (1981?). I have discussed the work of the mixed courts in John H. Langbein, Comparative Criminal Procedure: Germany (St. Paul, Minn.: West Publishing Co., 1977). 
extent may the mixed court be said to serve the purposes of the AngloAmerican criminal jury? Part I of the article outlines the principal features of mixed court structure and operation; it surveys what is known about the influence of the laymen vis-à-vis the professional judges and discusses some peculiarities of the process that the Germans use to select the laymen. Part II is devoted to the theory of the American jury; I have tried to identify the main purposes that criminal jury trial has been thought to serve in the common law tradition, in order to test the Continental mixed court for its fidelity to these principles. The conclusion is drawn that the mixed court cannot fully serve the panoply of jury policies but that it comes much closer than the indigenous devices-bench trial and plea bargaining - that have displaced jury trial from routine American practice. Accordingly, the suggestion is made that the mixed court could find a place in the United States within a hierarchy of trial modes.

\section{The German Mixed Courts}

Although the notion of lay participation in criminal adjudication traces back to Germanic antiquity, its only important survival in the late medieval world was the English jury. ${ }^{4}$ For cases of serious crime the courts of the early modern absolutist states of Europe were staffed exclusively with professional judges. At a time well before the independence of the judiciary had been established, these courts were subjected to political interference in cases that interested the rulers. ${ }^{5}$

Court structure was one of the major interests of legal reform efforts in the eighteenth century. Reform writers were certain that they wanted judicial independence, in order to eliminate executive interference in adjudication, but they were nonetheless distrustful of a judiciary that had for so long been under the heel of political authority. Accordingly, Beccaria and others popularized the English jury as a safeguard against judicial subservience. ${ }^{6}$

French experimentation with jury-like bodies commenced immediately after the Revolution. ${ }^{7}$ The form that ultimately emerged was a jury meant to decide all matters of "fact" but with questions of "law" reserved to the bench. This impossibly conceptual distinction was supposed to be implemented by having the jury render what amounted to a detailed special

4. The theme of John P. Dawson, A History of Lay Judges (Cambridge, Mass.: Harvard University Press, 1960).

5. See John P. Dawson, The Oracles of the Law 242-58 (Ann Arbor: University of Michigan Law School, 1968); Jürgen Regge, Kabinettsjustiz in Brandenburg-Preussen (Berlin: Duncker \& Humblot, 1977).

6. Cesare Beccaria, Of Crimes and Punishments, in Alessandro Manzoni, The Column of Infamy, prefaced by Cesare Beccaria's Of Crimes and Punishments, trans. Kenelm Foster \& Jane Grigson, 23 (London: Oxford University Press, 1964).

7. Adhémar Esmein, A History of Continental Criminal Procedure 408-18, 433-35, 460-61, 462-99 (trans. J. Simpson) (Boston: Little, Brown \& Co., 1913). 
verdict in response to interrogatories framed by the bench. Napoleon planted this institution in parts of Germany, especially on the Rhine where the French ruled until 1814. When the Revolution of 1848 forced rulers in the German states to acquiesce in demands for the criminal jury, ${ }^{8}$ the French model was widely instituted in a somewhat modified form; a special verdict system was retained, but jurors were also asked to express their view on guilt or innocence.

During the 1850 s and 1860 s the practical difficulties in operating this style of jury gave rise to considerable complaint in Germany, ${ }^{9}$ which ultimately led to experimentation with another mode of lay participation, the mixed court. Several of the German states developed versions of this socalled Schöffengericht, especially Hanover and Saxony; the Prussians embraced the mixed court after conquering Hanover. By the 1870s when unified national codes of procedure and court structure were being drafted, the Prussians sought to eliminate the jury court entirely in favor of the mixed court. The politics of the moment resulted in a compromise for the 1877 code that lasted until 1924: The jury court was retained for the most serious crimes, the mixed court tried the least offenses, and a wholly professional court exercised jurisdiction over a middle band of offenses. Dissatisfaction with the jury court never abated; it was abolished in favor of the mixed court in $1924 .^{10}$

The mixed court has, therefore, undergone fairly continuous alteration in structure and jurisdiction during the century since it was extended to the whole of Germany, ${ }^{11}$ and there is no reason to think that that process is at an end. ${ }^{12}$ As recently as 1975 some changes were made in the rules for selecting lay judges, and one infrequently used form of mixed court was eliminated. ${ }^{13}$

\section{A. The System in Outline}

In current practice ${ }^{14}$ mixed courts come in two basic varieties. A court of five judges-two lay and three professional-tries cases of more serious crime; this court is ordinarily known as the Grosse Strafkammer but

8. Erich Schwinge, Der Kampf um die Schwurgerichte (Breslau 1926).

9. Günther Hadding, Schwurgerichte in Deutschland: Der Schwurgerichtsgedanke seit 1848 (Kassel: Schneider \& Weber, 1974).

10. For an English-language summary of these developments see Casper \& Zeisel, supra note 1, at $136-41$.

11. By the Statute on Court Organization (Gerichtsverfassungsgesetz) of 1877, on whose history see Peter Landau, Die Reichsjustizgesetze von 1879 und die deutsche Rechtseinheit, in Vom Reichsjustizamt zum Bundesministerium der Justiz 161 (Cologne: Bundesanzeiger-Verlagsgesellschaft, 1977).

12. See Jescheck, supra note 3, at 232.

13. Discussed infra, text at note 69.

14. See generally Claus Roxin, ed., Strafverfahrensrecht 30-35 (16th ed. Munich: C. H. Beck, 1980); Eduard Kern \& Manfred Wolf, Gerichtsverfassungsrecht 150-58 (5th ed. Munich: C. H. Beck, 1975). 
is called the Schwurgericht when sitting for certain very serious offenses including homicides. Less serious crimes are tried to a court of three judges-two lay and one professional-still called the Schöffengericht. (Petty offenses are tried to a single professional judge, but from him there is a right of appeal de novo to a three-judge court, the Kleine Strafkammer, staffed with two lay judges and one professional.) For simplicity's sake and despite the inelegance, we shall speak of the two types of mixed courts by their composition figures, lay-judge figures first, as the Two-Three and Two-One courts.

In American procedure lay participation is highly waivable; the accused who is entitled to jury trial may elect to be tried by judge alone, or he may waive trial altogether by conceding guilt. ${ }^{15}$ In the vast proportion of cases he does one or the other. ${ }^{16}$ In modern German procedure the first option (waiver of lay participation) is unknown and the second (waiver of trial) is permitted only in cases so mild that the sanction of imprisonment cannot result. Furthermore, the German prosecutor cannot affect the right to lay participation in adjudication by manipulating his charging power; in cases of serious crime the celebrated rule of compulsory prosecution ${ }^{17}$ requires him to charge in the strongest and most inclusive form that the evidence will support. I have elsewhere explained the efficiencies that permit German criminal procedure to function without prosecutorial discretion and without plea bargaining; ${ }^{18}$ the present point is that lay participation under the mixed court system is not a merely nominal right, it is a reality for every case in which the sanction of imprisonment might apply.

A single statutory formula governs the voting arrangements in both the Two-Three and Two-One courts. Section 263(1) of the Code of Criminal Procedure provides that any decision that disadvantages the accused (meaning both verdict and sentence) must be taken with a two-thirds majority. In the Two-Three court this voting rule requires that a minimum four of the five judges agree upon a verdict of conviction. The two laymen have, therefore, a veto power if they act together; they can acquit over the opposition of the three professionals, but they cannot convict without the votes of two professionals. In the Two-One court that tries the lesser cases, the two-thirds voting rule allows the two laymen either to

15. The prosecution may insist on jury trial even if the accused wishes to waive it, but this seldom occurs. See Singer v. United States, 380 U.S. 24 (1965). In practice the only important election is the accused's.

16. I have collected some figures in John H. Langbein, Torture and Plea Bargaining, $46 \mathrm{U}$. Chi.

L. Rev. 3, 9 \& n.11 (1978).

17. See generally John H. Langbein, Controlling Prosecutorial Discretion in Germany, 41 U. Chi. L. Rev. 439 (1974).

18. On discretion, id.; on plea bargaining, John H. Langbein, Land Without Plea Bargaining: How the Germans Do It, 78 Mich. L. Rev. 204 (1979). 
convict and sentence or to acquit over the opposition of the professional. In either court the outcome of a trial is conviction or acquittal; there is no provision for stalemate comparable to the Anglo-American hung jury. (We shall deal below with empirical data on the actual operation of the voting rules.)

The professional judge or judges are responsible for preparing a written opinion to explain the court's findings of fact and law. In the event of conviction this opinion must also supply the reasoning for the court's sentence. ${ }^{19}$ This expansive document has, of course, no counterpart in the one- or two-word general verdict of the Anglo-American jury.

The requirement of a reasoned opinion supports a system of appellate review that departs markedly from Anglo-American expectations. The appellate system has a major effect on the operation of the mixed-court system. From any decision of the Two-One court there is a full appeal de novo (Berufung) to the Two-Three court. That is, no presumption of correctness attaches to the first-instance proceeding, and the case is fully retried. From the Two-Three court, whether sitting as a first-instance court in cases of serious crime or as a de novo trial court in cases once tried in the Two-One court, appeal lies only for error (Revision) and is heard by a court of five professional judges. ${ }^{20}$

Prosecution and defense have equal rights of appeal, on issues both of culpability and of sentence. German law adheres to the Continental tradition that appeal lies against acquittal as well as conviction (a question that once split the U.S. Supreme Court, ${ }^{21}$ with Justice Holmes arguing that our constitutional double jeopardy prohibition should not be construed to prevent the state's appeal of an acquittal).

On account of these differences, the prospect of appellate review presses more heavily on a German mixed court than on an Anglo-American jury court. This is a point to which we shall recur in discussing the influence of lay participation in the mixed-court system.

The mixed court retires at the conclusion of the oral public trial for deliberations in order to formulate its judgment. The presiding judge (the only professional in the Two-One court, the senior professional in the Two-Three court) "leads" these in camera proceedings and also, in the words of the statute, "puts the questions and takes the votes." 22 By convention the presiding judge (or, in the Two-Three court, another of the professionals) opens the deliberations by summarizing the evidence that has just been adduced at the trial. ${ }^{23}$

19. Strafprozessordnung (Code of Criminal Procedure) $\S 267(1)$.

20. See generally Roxin, supra note 14, at 281-312; for an English-language account, Langbein, supra note 3 , at $82-86$.

21. Kepner v. United States, 195 U.S. 100 (1904).

22. Gerichtsverfassungsgesetz $\S 194(1)$.

23. Casper \& Zeisel, supra note 1 , at 151 . 
Modern German mixed courts discharge their caseloads with enviable dispatch. The study by Gerhard Casper and Hans Zeisel established that an average trial for a serious offense in a Two-Three court lasts one day; trial in the Two-One court requires about two hours. ${ }^{24}$ The mixed-court structure accelerates German procedure by comparison with our own because it dispenses with the time-consuming features of the jury system that are so prominent in common law jury trials, especially the rules of evidence, jury instructions, and the other elements of jury control. (The extended voir dire of prospective jurors common in American jury practice is another source of delay that, we shall see, lacks any counterpart in the German mixed-court procedure.)

To be sure, factors other than mixed-court structure contribute to the efficiency of German criminal trials, including the economies associated with nonadversarial trial procedure. The presiding judge both "examines" and "cross-examines," after which he invites his fellow judges (professional and lay), the prosecutor, the defense counsel, and the accused to supplement his questioning. In conducting examinations, the presiding judge works from the official file of the case, the dossier, which contains the pretrial statements and public records gathered by police and prosecutors. These officials work under a statutory duty to investigate exculpatory as well as inculpatory evidence. This duty is reinforced in the pretrial phase by giving to the defense liberal rights to inspect the dossier, together with the right to motion the prosecution to investigate (at public expense) any defensive claims and evidence that might have been overlooked.

This thorough, open, and impartial pretrial preparation effectively eliminates surprise and forensic strategy from the trial. It also enables the presiding judge who determines the sequence of witnesses to control for relevance and to minimize needless duplication of trial testimony. Nonadversarial procedure assigns no burdens of proof to the parties. German law adheres to a standard of proof not materially different from our "beyond reasonable doubt"; but without the system of adversary presentation of evidence, there is no occasion to think of the "prosecution case" (or, indeed, of the defendant's burden of proving an "affirmative defense'). The only burden is the court's. In order to convict, the court must satisfy itself of the truth of the charges after taking the relevant evidence, including that requested by prosecution and defense. Thus, the court that must decide the case conducts its own trial inquiry in a businesslike and undramatic fashion, overseen by prosecution and defense. ${ }^{25}$

No modern system can delegate unrestrained powers of criminal ad-

24. Id. at 149-51. American trial duration data is collected in Langbein, supra note 16 , at 10 \& n.18.

25. This and the previous paragraph are derived from Langbein, supra note 18, at 207-8. 
judication to laymen-that is, to people who lack legal training and experience and who do not bear professional responsibility for their work. The Anglo-American jury system, by isolating the laymen, complicates the task of safeguarding against the dangers of ignorance and bias that inhere in any attempt to use laymen in adjudication. Because the jury deliberates without professional participation and decides without giving reasons, there is virtually no opportunity to provide learned guidance to the jurors during deliberations, and the means of detecting and relieving against errors after verdict are quite limited. Accordingly, our system of jury control has been designed to work anticipatorily. Voir dire is supposed to discover and reject for service potential jurors who would not be fair-minded, notwithstanding the difficulty of making such predictions and the amount of time that the process can require. We conceive of potential error, and we try to prevent it. The law of evidence is meant to exclude from jurors information whose relevance they might misapprehend, but the cost of this exclusionary system in time and complexity is immense. The trial judge's instructions ostensibly identify and resolve for the jurors in advance of their deliberations the legal problems that may arise, although the format of multiple contingent instructions protracts the trial and probably bewilders the jurors. ${ }^{26}$

The mixed court relies upon three quite different safeguards against lay inexperience: the presence of professional judges in deliberations, the requirement of reasoned opinion, and liberal appellate review. Professional judges discuss the rules of law and caution against unfounded uses of evidence in camera when and if the need arises. Since these deliberations occur out of the presence of counsel, the requirement of written opinion is a central protection. Important findings of fact and rulings of law are meant to show up in the judgment and be subject to appeal. Collegiality serves as another protection against judicial arbitrariness or error in the deliberations, because three professionals sit in the Two-Three trial court (and in the Two-Three court that proceeds by trial de novo in appeals from the Two-One court).

\section{B. Influence of the Laymen}

By comparison with the Anglo-American jury system, the German mixed court enhances lay authority in certain significant respects. In the mixed court the lay judges participate in determining sentence as well as verdict, whereas at common law the work of the criminal jury ceases with the verdict, and only relatively minor statutory intrusions into sentencing

26. "Juries have the disadvantage ... of being treated like children while the testimony is going on, but then being doused with a kettleful of law during the charge that would make a third-year law student blanch." Curtis Bok, I Too, Nicodemus 261-62 (New York: Alfred A. Knopf, 1946). 
have been made. ${ }^{27}$ German lay judges also participate in all rulings of law; and, accordingly, no exclusionary rules can be employed to limit their view of the evidence.

In other respects, however, the mixed court diminishes lay authority. Laymen are much fewer in number, and they do not act independently of the professionals. They have the power to force acquittal, but only in the Two-One court for lesser offenses can they convict without professional assent. The requirement of reasoned opinion exposes the judgments of the mixed courts to deep-reaching appellate review at the behest of either the defendant or the prosecution.

One serious attempt has been made to measure the influence of the laymen in the German mixed courts. In their landmark empirical study undertaken a decade ago, Casper and Zeisel compiled a careful sample of about six hundred cases from both types of mixed courts. ${ }^{28}$ Following to some extent the methodology of the earlier American Jury ${ }^{29}$ project, the investigators had professional judges reply anonymously to a standardized questionnaire about the mixed-court trials in which they presided. One object of the study was to identify the proportion of cases in which lay and professional judges found themselves in initial disagreement and then to see how frequently the laymen persisted in their views.

The main findings of this aspect of the Casper and Zeisel study may be summarized as follows: ${ }^{30}$

1. On the question of guilt (verdict), some lay and professional judges in the mixed courts found themselves in some disagreement at the outset of their deliberations in 6.5 percent of all cases.

2 . On the question of sentence, where the range of permissible outcomes is much broader than on verdict, some initial disagreement between lay and professional judges occurred in 20.1 percent of all cases.

3 . In the 6.5 percent of the cases in which there was initial disagree-

27. See McGautha v. California, 402 U.S. 183 (1971), where the bifurcated California procedure and the unitary Ohio procedure for jury determination of death sentences were upheld.

The National Advisory Commission on Criminal Justice Standards and Goals said in its Report on Courts, Standard 5.1, at 110 (Washington, D.C.: Government Printing Office, 1973), "Jury sentencing should be abolished in all situations." It explained:

Although 13 States still allow jury sentencing in noncapital cases, the practice has been condemned by every serious study and analysis in the last half-century. Jury sentencing is nonprofessional and is more likely than judge sentencing to be arbitrary and based on emotions rather than the needs of the offender or society. Sentencing by juries leads to disparate sentences and leaves little opportunity for development of sentencing policies.

Id., Commentary. This hostility to jury participation in sentencing is widespread; it is quite difficult to reconcile with the supposed virtues of the jury in matters of verdict, discussed below in part II of this article.

28. For detail on the study design, including the weighting of certain data, see Casper \& Zeisel, supra note 1 , at $143-46$.

29. Harry Kalven, Jr., \& Hans Zeisel, The American Jury (Boston: Little, Brown \& Co., 1966).

30. Casper \& Zeisel, supra note 1, at 185-91. 
ment on guilt, one or more of the lay judges persisted in voting against the professionals in 30 percent of the cases; in 21 percent (mostly in the Two-One court) the lay votes affected the verdict. These cases in which lay voting altered the outcome constituted 1.4 percent of the entire sample of cases.

4. Lay influence on sentencing was greater, in part because sentencing disagreements were often resolved by compromise. The lay votes affected 32 percent of the cases in which there was initial disagreement, or 6.2 percent of the entire sample of cases.

Commenting on their findings, Casper and Zeisel remarked that the "traceable overall effect of the lay judges on the verdicts of the German criminal courts is indeed small... . Compared to the American jury, the difference is marked. American juries arrive at a verdict that is different from that of the presiding judge in 22 percent of all cases [according to the American Jury data]." ${ }_{31}$

The contrast between a 1.4 percent figure for lay influence on verdict in the German mixed court and a 22 percent figure in the American jury court needs to be probed with care. If the contrast were a fair one, it would indicate that the laymen in the German procedure are far less influential than American jurors, and it might incline us to suspect that the purposes attributed to the jury system are not being served at adequate levels in the German mixed courts. In my view, however, the contrast is seriously misleading for several reasons:

1. It does not correct for the marked disparity between the two groups of cases. In Germany every case of serious crime goes to trial before one of the mixed courts. In the United States only the tiny fraction of cases that have resisted negotiated diversion (primarily plea bargaining) go to trial. Most of the easy cases, where disagreement between judge and jury would be least likely, have been filtered out of the American trial statistics. Indeed, in calculating their 1.4 percent figure for Germany, Casper and Zeisel did not exclude the 41 percent of their case sample in which the accused confessed at trial, making disagreement about guilt a practical impossibility. ${ }^{32}$

2. The 1.4 to 22 contrast overlooks the import of the relatively substantial 6.2 percent figure for lay influence on sentencing in the German mixed court. In the American system where the jury is excluded from direct participation in sentencing, it is by the manipulation of degrees and counts that the jury brings what are in truth sentencing considerations to bear on the outcome. The 22 percent American figure for judge/jury disagreement on guilt includes disagreements over offense characterization and the number of counts that are mostly sentencing disputes in function.

32. This and the next paragraph are derived from Langbein, supra note 3, at 137-38. 
3. The assumption that the measure of lay influence is persistence in disagreement with the professionals is misleading if it implies that laymen yield because they are intimidated rather than persuaded. The Casper and Zeisel study describes the circumstances in a number of the deliberations in which the laymen yielded after initial disagreement. These were in general cases in which the professional judges were unmistakably correct on rational, legal, and humanitarian grounds. ${ }^{33}$ Judicial persuasion prevented lay intolerance or misunderstanding from resulting in injustice.

4. Lay participation has a predominantly preventive purpose. As I shall emphasize below in part II when discussing the jury policies, the presence of laymen is meant to deter professional judges from political subservience and from arbitrariness. A system of lay participation that serves these goals quite fully need leave no trace in lay/professional disagreement. The methodology of the Casper and Zeisel study simply does not address this realm of lay influence.

To conclude: There are some respects in which it is fair to say that two laymen who are merged with one or three professional judges lack the authority of a dozen laymen who possess the exclusive verdict power. But the laymen on the mixed court are fully informed; no law of evidence has concealed probative matter from them, no system of jury control has been employed to cordon them off from the totality of criminal adjudication. Rather, their votes extend to matters of law and of sentence. The implication in the Casper and Zeisel study that lay influence in the German mixed courts is inadequate, and that it is materially below the levels achieved in Anglo-American jury courts, is neither supported by the empirical data, nor properly appreciative of factors that an empirical study cannot measure. Indeed, there is good reason for treating this one objectionable passage in an otherwise masterful piece of scholarship as nothing more than an offhand remark; it was a digression in a work whose main inquiry into the German practice was not comparative. A decade later an occasion did arise for comparative consideration of the findings of the Casper and Zeisel article-in the course of judicial proceedings. In an affidavit to an American court convened in 1979 for a remarkable criminal trial in Berlin, Dean Casper said of the comparative significance of the Casper and Zeisel study: "Our study clearly indicates that German lay judges exercise independent judgment in criminal cases, and do serve a societal purpose comparable to that of American juries-namely, injecting the values, experiences, and judgments of the lay community into the adjudication process." 34 in West Berlin, 55 Notre Dame Law. 682, 696 (1980). 


\section{Selection of Lay Judges}

Lay judges serve four-year terms. Each layman sits for several days per year-once a month is the pattern suggested by statute. ${ }^{35} \mathrm{He}$ acquires as his term advances some general familiarity with trial procedure and the work of adjudication, although hardly enough to feel socialized into professional legal culture. The process for choosing lay judges every fourth year is divided into a nomination and a selection phase. The governing statute $^{36}$ prescribes some fairly obvious disqualifications (incapacity, age, officeholding, and so forth) but otherwise provides the authorities with little guidance on how they should construct their lists.

A valuable empirical study by Ekkehard Klausa has shown that there is great diversity in the nomination practices of the local authorities. ${ }^{37}$ Klausa found some authorities compiling an essentially random list of residents. Other authorities effectively delegated the task to the political parties represented on the city council. In Berlin the authorities allowed the police to exercise a veto power over the provisional list.

In Augsburg, where I interviewed the administrator in charge of compiling the 1980 nomination list, ${ }^{38}$ the local authority was pursuing a vigorous policy of encouraging citizens to volunteer for lay judging service. The cooperation of the local press had been enlisted to publicize the work of the lay judges and to advise citizens how to apply for service by phone or in person. This campaign for volunteers was undertaken at the behest of the professional judiciary, which had communicated the view that citizens who displayed such interest in serving made "better" lay judges than did forced recruits. The Augsburg authority needed to compile a list of 739 nominees. It obtained 384 volunteers. It then asked the political parties in the city council to supply the remainder, in proportion to their representation on the council. The parties were not able to supply that many; they named 221 people. The remaining 134 names needed to complete the list were computer generated in a random manner from the local population list. Augsburg's relative success at getting volunteers contrasts with the experience in the North German cities studied by Klausa, where volunteers were not a significant component of the nominees. He found, for example, that the authority in Cologne had abandoned the practice of

35. Gerichtsverfassungsgesetz $\S 43(2)$. The statute says "twelve regular session days per year," and the practice is to spread them.

36. Id. §§ 32-36.

37. Ekkehard Klausa, Ehrenamtliche Richter: Ihre Auswahl und Funktion, empirisch untersucht 23-46 Frankfurt (Main): Athenäum-Verlag GmbH (1972). For an English-language summary see Langbein, supra note 3, at 142-44. For similar findings from a different data base see Casper \& Zeisel, supra note 1 , at 183 .

38. Interview, Einwohnermeldeamt der Stadt Augsburg, June 27, 1980. 
campaigning for volunteers for want of adequate response, and that volunteers there constituted only 5 percent of the total. ${ }^{39}$

In the second phase of the selection process a selection commission chooses which nominees will become lay judges. The number to be chosen is set by an officer of the criminal court, who estimates the number of lay judges that will be needed for the likely caseload. ${ }^{40}$ The selection committee is chaired by a judge and contains, in addition to an administrator from the state government, ten citizens chosen by the elected local governments within the judicial district. ${ }^{41}$ In practice these ten members of the selection commission are chosen by the political parties in proportion to the parties' representation on the local councils. The commission decides by two-thirds majority vote. Klausa found considerable diversity in the working methods of the commissions. ${ }^{42}$ In Berlin the parties received the list of nominees in advance of the commission meeting; each party designated a number of lay judges proportionate to its representation on the commission, whose actual meeting was therefore perfunctory. Elsewhere, party influence on selection was more indirect. Selection commission members did not seem to prefer fellow party members as such, but they did express a preference for people they knew personally, and often those people had shared party affiliations.

Apart from personal acquaintance, the datum regarded as most relevant by selection commission members was occupation (information that appears with the names on the local population records from which the names are obtained). Members thought that it was important to achieve a wide distribution of occupations, but they went about it casually. There was a favorite group of occupations: teachers, civil servants, social workers, administrative personnel. As a result civil servants and other whitecollar personnel were relatively overrepresented, housewives and bluecollar employees relatively underrepresented. ${ }^{43}$

In Augsburg, the local authority advised the selection commission which of the nominees were volunteers, which party designated, and which computer generated, on the theory that the commission would probably prefer to avoid the computer-generated nominees. ${ }^{44}$

Once the selection commission has chosen the cohort of lay judges, the administrative office of the court assigns them quite randomly to particular chambers and dates of attendance. (Similar procedures are used to as-

39. Klausa, supra note 37 , at 28.

40. Gerichtsverfassungsgesetz $\S 43(1)$.

41. Id. $\S 40$.

42. Klausa, supra note 37 , at $30-47$.

43. Id. at 33-47.

44. Interview, Einwohnermeldeamt der Stadt Augsburg, June 27, 1980. 
sign alternates for service in the event of illness or other incapacity. $)^{45}$ Lay judges may thereafter be challenged by prosecution or defense only on those grounds of relationship or prejudice for which professional judges may be recused; 46 this happens with the greatest rarity. Consequently, there is no analogue to the voir dire of an American jury.

Although the statute states that the list of nominees should be representative of "all groups in the population," ${ }^{47}$ neither the statutory procedures nor the practices of the local authorities and commissions seem directed to that end. The emphasis on getting people who are interested in lay judging, or who are known to the local elected officials and party leaders, as well as the commissions' preference for white-collar occupations, produces a group of laymen whose educational and social background is rather closer to that of the professional judges. Of course, other groups of the population are merely underrepresented, not excluded.

In sum, this selection system has a haphazard quality that contrasts curiously with the meticulous design of the court system it serves. The well-intentioned efforts to identify citizens who are interested in lay judging and who feel comfortable with the job may-by reducing the diversity of the lay cohort-diminish the effectiveness of the lay role.

\section{The Mixed Court and the Goals of the Jury System}

In 1968 the Supreme Court held in Duncan v. Louisiana "that the Fourteenth Amendment guarantees a right of jury trial in all criminal cases which-were they to be tried in a federal court-would come under the Sixth Amendment's guarantee." ${ }_{48}$ Duncan led in the 1970s to a series of cases questioning the constitutionality of various state schemes for nonunanimous jury verdicts and juries of fewer than 12 members. In companion cases decided in 1972, Johnson v. Louisiana ${ }^{49}$ and Apodaca $v$. Oregon, ${ }^{50}$ the court sustained nonunanimous verdicts of 12 -member juries. In 1970 in Williams $v$. Florida ${ }^{51}$ the court approved a jury of 6 persons; in 1978 in Ballew v. Georgia ${ }^{52}$ it disapproved a jury of 5; and in 1979 in Burch v. Louisiana ${ }^{53}$ it held that the verdict of a jury of 6 must be unanimous.

In these recent jury cases appear succinct statements of the Court's understanding of the purposes of the constitutional jury guarantee. They

45. Gerichtsverfassungsgesetz $\S 45$.

46. Strafprozessordnung $\S \S 22,24-31$.

47. Gerichtsverfassungsgesetz $\S 36(2)$.

48. 391 U.S. 145 (1968).

49. 406 U.S. 356 (1972).

50. 406 U.S. 404 (1972).

51. 399 U.S. 78 (1970).

52. 435 U.S. 223 (1978).

53. 441 U.S. 130 (1979). 
form a convenient repository of sources for our inquiry, which is to identify in functional terms the main purposes that the criminal jury is thought to serve. (The object, it has been said, is to test the mixed court against these standards. Our interest is in the comparative merits of two forms of lay participation in criminal adjudication. Accordingly, we shall not have occasion to lengthen our view of the purposes of the jury beyond its adjudicative role to the higher realms of social and political theory, where discussion can be found of the significance of lay participation for promoting social solidarity and legitimating public authority.)

\section{A. The Purposes of the Criminal Jury}

\section{The Jury Is Nonbureaucratic}

Of the many purposes attributed to the jury, one stands out as paramount. The power to condemn citizens to criminal sanctions is potentially so dangerous that it ought not to be left entirely to hirelings of the state. "Those who wrote our constitutions," said Justice White in Duncan, "knew from history and experience that it was necessary to protect against unfounded criminal charges brought to eliminate enemies and against judges too responsive to the voice of higher authority. The framers of the constitutions strove to create an independent judiciary but insisted upon further protection against arbitrary action." 54 Jury trial gives the accused "an inestimable safeguard against the corrupt or overzealous prosecutor and against the complaint, biased, or eccentric judge. ... Fear of unchecked power, so typical of our State and Federal Governments in other respects, found expression in the criminal law in this insistence upon community participation in the determination of guilt or innocence." ss

A similar theme runs through the nineteenth-century European history of adaptation of the jury, ${ }^{56}$ although it has begun to be questioned in modern German thinking. ${ }^{57}$

The essence of the safeguard is the relative independence of the laymen. Laymen do not depend for their livelihood on the favor of the authorities who staff the criminal justice system. Unlike professional judges, they do not have an interest in professional advancement that might tempt them to abide political interference. Hence, they lack incentive to defer to corrupt or otherwise willful misuse of the criminal process.

Every modern criminal procedural system contains many safeguards against abusive prosecution and judicial connivance, quite apart from lay participation in adjudication. Yet because the standard of proof must be

54. 391 U.S. at 156.

55. Id.

56. Schwinge, supra note 8, passim.

57. Jescheck, supra note 3, at 237-38; Kern \& Wolf, supra note 14, at 152. 
subjective, criminal adjudication still depends upon the good faith of the trier. The presence of laymen is not a foolproof safeguard; the professionals have opportunities to deceive the laymen in either system, jury or mixed court. Against that danger both systems have appellate checks-review of trial rulings and jury instructions in our system and substantive review of the verdict and sentence of the German mixed courts. Lay participation is above all a deterrent safeguard, and in neither system is there evidence that it has failed to deter the professional judiciary from political subservience in criminal adjudication.

\section{The Jury Is Collegial}

In Anglo-American law, where the notion of a collegial trial bench has largely disappeared, the jury is our only device for bringing group decision making to criminal adjudication. This aspect of the jury's function is alluded to in the Duncan opinion when the Supreme Court speaks of the jury as a check against "arbitrary action"' by the judiciary or the misbehavior of an "eccentric judge." 58

The mixed court is at least as effective as the jury at checking judicial eccentricity. The Anglo-American trial judge acts without lay participation on evidentiary and other trial motions; most importantly, his discretion in sentencing is untempered by the lay hand. ${ }^{59}$ In the German mixed court system each professional must reckon with the participation of two other professionals in the Two-Three courts for major offenses; and in whichever mixed court a professional sits, he is joined by two laymen at every step of trial, deliberation, verdict, and sentence. Thereafter he is obliged to join in a reviewable opinion explaining his view of the evidence and the law.

Collegiality is, of course, not unrelated to concerns about numerosity of lay viewpoints that were at issue in the jury size cases and which we discuss below under the rubric of jury representativeness.

\section{Jurors Bring Lay Skills}

A certain amount of ignorance has been thought to be a virtue in criminal adjudication. It has been argued that involving citizens who are neither legally trained nor routinely engaged in the administration of criminal justice brings positive benefits. (There are, of course, counterarguments, but that is beside the point.)

a) Laymen bring freshness. Professional judges with long experience in criminal adjudication may become calloused. Because laymen have not

58. 391 U.S. at 156.

59. But see note 27 supra. 
heard the same alibi a hundred times before, they may be more alert to its merits in the occasional case in which it is not false.

b) Laymen are sometimes said to be better fact finders and law appliers than professional judges, because they are closer to the affairs and experience of ordinary folk. The claim is sometimes heard that the common sense of laymen is preferable to the learning of the professional judge in evaluating credibility, or in applying community-based standards of conduct such as negligence or recklessness.

c) Laymen are a force for simplification in the administration of criminal justice. When procedure and substance must be made comprehensible to ordinary citizens, the law is more likely to be formulated simply, which in turn promotes fair warning and thereby contributes to the deterrent purpose of the criminal law.

Whatever weight is attached to these policies, it seems unlikely that there is much to choose from between jury and mixed court in achieving them. In either format the professionals must make themselves understood to the laymen, and the laymen will bring whatever folk wisdom they possess.

\section{The Jury Represents the Community}

The Supreme Court's decision authorizing the jury of 6 in Williams $v$. Florida asserted that the difference between 12 and 6 jurors was not functionally significant, hence not of constitutional dimension. Some valuable empirical scholarship done after Williams casts a good deal of doubt on that proposition. Justice Blackmun's opinion relied heavily on this work in Ballew v. Georgia, where the court refused to legitimate a jury smaller than $6 .{ }^{60}$

The main theme of the scholarship that Blackmun's opinion in Ballew follows is that the quality of jury decision making is positively correlated with group size. ${ }^{61}$ Some of the proofs of this proposition were related to peculiar features of jury structure. For example, it was shown that larger juries have more opportunities to remember important evidence, a feature that was thought to be of consequence because most juries do not (and indeed are often not allowed to) take notes. ${ }^{62}$ But empirical results of a more telling nature were canvassed in the Ballew opinion:

a) "[T]he smaller the group, the less likely it is to overcome the biases of its members to obtain an accurate result. When individual and group decisionmaking were compared, it was seen that groups performed better

60. 435 U.S. 223 (1978).

61. Id. at 231-33, esp. Richard O. Lempert, Uncovering "Nondiscernible" Differences: Empirical Research and the Jury-Size Cases, 73 Mich. L. Rev. 643 (1975).

62. 435 U.S. at 233 and sources cited id. at n.13. 
because prejudices of individuals were frequently counterbalanced, and objectivity resulted. Groups also exhibited increased motivation and selfcriticism. All these advantages, except, perhaps, self-motivation, tend to diminish as the size of the group diminishes. Because juries frequently face complex problems laden with value choices, the benefits are important and should be retained. In particular, the counterbalancing of various biases is critical to the accurate application of the common sense of the community to the facts of any given case." 63

b) Several studies raised doubts "about the accuracy of the results achieved by smaller and smaller panels." ${ }_{64}$ In one experiment the proportion of inconsistent verdicts increased as jury size decreased; another study showed greater variability of compromise results in smaller panels. ${ }^{65}$

c) Smaller juries decrease the likelihood that jurors will adhere to a minority view. "The chance for hung juries would decline accordingly." 66 This "foretells problems not only for jury decisionmaking, but also for the representation of minority groups in the community. The Court repeatedly has held that meaningful community participation cannot be attained with the exclusion of minorities or other identifiable groups from jury service." 67

It would be very difficult to reconcile the German mixed courts of two laymen with the values of numerosity that the Supreme Court elevated to constitutional dimension in Ballew. The largest of the German panels contains 5 judges, professional and lay; 5 was the jury size that Ballew held insufficient. There are, of course, factors that work to lessen the significance of the contrast between mixed courts containing 2 laymen and jury courts with 6 or 12 . The participation of professional judges in deliberation is a force for modulation of lay bias without counterpart in jury trial. The requirement of written findings and opinion, coupled with the liberality of appellate review, is the main German safeguard against inaccurate adjudication. And the Ballew opinion overstates the representativeness of the jury, because it does not allow for the effects of the American voir dire and challenge practice in reducing the representativeness of jury panels.

Mixed courts with larger numbers of laymen function elsewhere in Europe ${ }^{68}$ Indeed, until 1975 the Germans used a panel of six lay and three professional judges for the gravest offenses (the Schwurgericht). That court has since been reconstituted as a Two-Three court. This reduction

63. Id. at 233-34 (footnotes omitted).

64. Id. at 234 .

65. Id. at 234-35.

66. Id. at 236 .

67. Id. at 236-37.

68. See Casper \& Zeisel, Laienrichter, supra note 1, at 9. 
from six laymen to two was legislated in 1974 without controversy, ${ }^{69}$ on the view that the purposes of lay participation were as well served with two as with six. The official commentary to the draft statute ${ }^{70}$ says, in an unilluminating paragraph, that the need for the laymen to preponderate has disappeared now that the state is more trustworthy and the independence of the professional judiciary has been secured. The modern object, says the commentary, is to facilitate the cooperation of lay and professional judges, for which goal the smaller panel is more fit; and the voting rule does preserve the power of the two laymen on the Two-Three court to resist conviction. Implicit in this statement is the view that larger courts tend to produce more divergence of view, ${ }^{71}$ as Justice Blackmun said in Ballew; but that this is not a virtue in a system that combines lay and professional duties and that makes the product liable to searching review.

\section{The Jury May Decide Contrary to Law}

The jury's celebrated law-nullifying power takes advantage of two features of Anglo-American practice that are without counterpart in the German mixed-court system: the general verdict that conceals the grounds of decision, and the rule against prosecutorial appeal from acquittal. The debate about the merits of the law-nullifying power can be followed in the large literature ${ }^{72}$ that it has engendered. To the claim that the jury serves as a mini-legislature protecting citizens against unjust laws, the response is made that law nullifying is a sorry excuse for law reform; it leaves bad laws on the books and begets inconsistent results in like cases. To the view that nullification permits the jury to do equity in harsh cases, the response is that jury sympathy does not always favor the angels. ${ }^{73}$

The German mixed-court system effectively excludes law nullifying from the lay functions. The professional judges are duty-bound to disclose erroneous grounds of decision in the written judgment that they

69. The one critical voice of note: Richard M. Honig, Ehrenamtliche Richter im Schwurgericht, 28 Monatsschrift für Deutsches Recht 898 (1974).

70. Gesetzentwurf der Bundesregierung, Entwurf eines Ersten Gesetzes zur Reform des Strafverfahrensrechts (Drucksache 7/551) 54 (Bonn: Verlag Dr. Hans Heger, 1974).

71. Casper and Zeisel obtained a small amount of data from the former nine-judge Schwurgericht, in which they did find greater divergence. Casper \& Zeisel, supra note 1, at 175-80.

72. Compare Dale W. Broeder, The Functions of the Jury: Facts or Fictions? 21 U. Chi. L. Rev. 386 (1954), with Alan W. Scheflin, Jury Nullification: The Right to Say No, 45 S. Cal. L. Rev. 168 (1972).

73. For further discussion of the jury policies see the effort at cataloging pros and cons that was submitted by the University of Chicago Jury Project as "Memorandum Regarding Jury System," in Recording of Jury Deliberations: Hearings Pursuant to S. Res. 58 Before the Subcommittee to Investigate the Administration of the Internal Security Act and Other Internal Security Laws of the Committee on the Judiciary, U.S. Senate, 84th Cong., 1st Sess., 63-81 (1955). See also Patrick Devlin, Trial by Jury (rev. 3d impression; London: Stevens \& Sons, Ltd., 1966). 
prepare for the mixed court. Accordingly, laymen preparing to bend or disregard the law confront professionals who say, "This will not stand up on appeal." Reasoned judgment and appeal-those safeguards of the German system that figure so recurrently when we examine the differences between the systems-are here decisive in precluding an arguable safeguard.

\section{B. Pluses and Minuses}

The results of the inquiry we have been conducting may be summarized in three propositions. (1) In a few important respects the mixed court serves the jury policies better than the jury itself. (2) Over most of the range of jury policies there is little to choose between the two systems. (3) But there are key jury policies that are diminished in mixed-court procedure.

The first and last of these points require amplification.

The mixed court extends lay participation to sentencing (which is the sphere of criminal adjudication in which the legal training of the professional judge may be thought to be least relevant). Since German criminal justice forbids any form of nontrial disposition for imprisonable offenses, there is lay participation in every sentencing decision in cases of truly serious crime. One of the most interesting discoveries of the Casper and Zeisel study was that in the 41 percent of the case sample in which the accused had confessed, the time spent by the mixed court on deliberation (as distinct from trial) differed "hardly at all" 74 from the cases in which guilt was contested. This enabled the authors to infer that in both types of cases "the bulk of deliberation time is devoted to the sentencing issue." 75 It should also be recalled that Casper and Zeisel found initial lay/professional disagreement concerning sentence in 20.1 percent of their cases, and that the lay judges persisted in their view and affected the outcome in 32 percent of these cases. In providing laymen this voice in sentencing, the mixed court advances all of the jury purposes in an immensely important area of criminal adjudication from which the common law tradition excludes the jury.

The mixed court also serves the jury purposes at a higher level by informing the laymen better. Because the device of integrating lay and professional judges spares the mixed court the need for evidentiary exclusions or other attempts at jury control, the laymen hear the full case rather than the fragments to which our system restricts jurors.

Beyond question, however, the limitations on lay autonomy that are integral to the mixed-court system would disserve the purposes of the jury system in two significant respects. In the matter of numerosity and

74. Casper \& Zeisel, supra note 1 , at 150.

75. Id. 
the values associated with it, there would be great difficulty in equating 2 laymen with 6 or 12, if that feature of current German court structure were retained. Further, the mixed court quite deliberately suppresses the law-nullifying impulse by having professional judges sit with the laymen and be responsible for disclosing the grounds of decision in a reviewable written judgment.

\section{Emulating the Mixed Court}

The initial premise of this article, to which we can now return, is that Americans looking for solutions to the intractable problems of our criminal procedure might find the mixed court a worthy object of emulation. Both on account of its own efficiencies, and because it would be likely to promote some of the further efficiencies associated with nonadversarial procedure, the mixed court could be thought to be an improvement over the institutions of a criminal justice system that has lost most of its capacity to adjudicate criminal cases.

In Duncan v. Louisiana Justice White took pains to point out that even the constitutionalization of jury trial mandated for the states in that case would not necessarily preclude a state from undertaking an institutional and procedural reconstruction of its criminal justice system so fundamental that the end result could be juryless. "A criminal process which was fair and equitable but used no juries is easy to imagine. It would make use of alternative guarantees and protections which would serve the purposes that the jury serves in the English and American systems." $76 \mathrm{We}$ have seen why the mixed court may be claimed to have those qualities of alternative safeguard that the opinion in Duncan envisages.

If we were to explore such a wholesale choice of systems, the proponent of the mixed court would frame the question thus: Which is more desirable, a system that slightly impairs some of the less important jury values, but that is so efficient that it can permit-indeed require-full trial with lay participation in every case of serious crime? Or a system that nominally preserves all the purposes of the jury system but that is so complex and costly that jury trial can only be used exceptionally?

However intriguing this formulation of the question, the issue it raises is scarcely worth pursuing. In order totally to excise jury trial from an Anglo-American criminal procedural system, it would be necessary to overcome centuries of experience, now distilled into ideology and mythology, and entrenched in federal and state constitutions.

The main point to be drawn from the comparison of jury court and mixed court is the mixed court's superiority, not to the jury, but to the other institutions that we now use to dispatch the vast preponderance of 
our criminal caseloads: bench trial and plea bargaining. The mixed court is an exceptionally good second best; it does not fully serve the jury policies, but bench trial and plea bargaining abandon all the jury policies. Bench trial eliminates lay participation from adjudication; plea bargaining eliminates not only lay participation but adjudication itself.

The Supreme Court cases from Duncan to Ballew which reaffirm the jury policies in constitutional dimension are profoundly deceptive. For in the same years that it decided these cases, the Court placed its imprimatur ${ }^{77}$ on the system of plea bargaining that has effectively eliminated the role assigned to the jury in the Bill of Rights. The Framers thought that they had made jury trial the exclusive mode of dealing with cases of serious crime. The Sixth Amendment says: "In all criminal prosecutions, the accused shall enjoy the right to . . . trial . . . by an impartial jury . . .."78

The Sixth Amendment meant what it said when it was drafted in 1791. Well into the nineteenth century, jury trial was the routine dispositive procedure for cases of serious crime. Bench trial-that is, trial by a professional judge sitting without lay participation of any sort-developed in the United States in the second half of the nineteenth century and was not made generally available until well into the twentieth century. ${ }^{79}$ Contemporary legal thought resisted bench trial for cases of serious crime, precisely because it so impaired the purposes of the jury guarantee. ${ }^{80}$ To this day there is no analogue to bench trial in English criminal procedure for the most serious categories of crime. The trial of a defendant accused of murder, rape, or robbery can only be by jury.$^{81}$ Plea bargaining is also an American invention of the nineteenth century, ${ }^{82}$ in the previous century trial courts actively discouraged attempts to plead guilty, urging defendants to accept jury trial instead. ${ }^{83}$

Well into the eighteenth century jury trial was still a summary proceeding, and that is largely how the Framers conceived of it. For example, at

77. Bordenkircher v. Hayes, 434 U.S. 357 (1978); Santobello v. New York, 404 U.S. 257 (1971); North Carolina v. Alford, 400 U.S. 25 (1970); Brady v. United States, 397 U.S. 742 (1970); McMann v. Richardson, 397 U.S. 759 (1970); Parker v. North Carolina, 397 U.S. 790 (1970).

78. U.S. Const. amend. VI (emphasis added).

79. See John H. Langbein, Understanding the Short History of Plea Bargaining, 13 Law \& Soc'y Rev. 261, 269-70 (1979).

80. The Connecticut Supreme Court upheld a statute authorizing bench trial under the state constitution but recorded its disapproval. The opinion says that it is "impolitic and unwise . . . to place the life or liberty of any person accused of crime, even by his own consent, at the disposal of any one man or two men, so long as man is a fallible being." State v. Worden, 46 Conn. 349, 367 (1878).

81. Unless, of course, the defendant waives all trial by pleading guilty. See R. M. Jackson, The Machinery of Justice in England 183 (7th ed. Cambridge: Cambridge University Press, 1977).

82. Albert W. Alschuler, Plea Bargaining and Its History, 79 Colum. L. Rev. 1 (1979); Langbein, supra note 79.

83. See the evidence in John H. Langbein, The Criminal Trial Before the Lawyers, 45 U. Chi. L. Rev. 263, 278-79 (1978). 
the Old Bailey in London (which was the main criminal trial court of the Anglo-American world), when the court sat it tried between 12 and 20 cases of felony per day. ${ }^{84}$ Indeed, it was not until 1794 that a trial "ever lasted for more than one day, and [in that case] the Court seriously considered whether it had any power to adjourn ...."8s By contrast, we may note that the trial of Patricia Hearst for bank robbery in 1976 lasted 40 days, ${ }^{86}$ and that the average felony jury trial in Los Angeles in 1968 required 7.2 days of trial time. ${ }^{87}$

The astonishing rapidity of eighteenth-century jury trial can be traced to a variety of features that have since changed: ${ }^{88}$

1. Neither prosecution nor defense was represented by counsel in ordinary criminal trials. The victim or other complaining witness, sometimes aided by the lay constable and the lay justice of the peace, performed the role we now assign to the public prosecutor, gathering evidence and presenting it at trial.

2. There was no counsel-conducted voir dire of prospective jurors. In practice the accused took the jury as he found it and virtually never employed his challenge rights. Indeed, at the Old Bailey only two 12-man jury panels were used to discharge the entire caseload of as many as a hundred felony trials in a few days. Each jury usually heard several unrelated cases before deliberating on any. For comparison we may point to the voir dire in the 1970-71 trial of Bobby Seale in New Haven that lasted four months and involved the vetting of 1,035 prospective jurors. ${ }^{89}$

3. The most efficient testimonial resource available to a criminal court is almost always the criminal defendant. He has, after all, been close enough to the events to get himself prosecuted. In modern Anglo-American procedure we have constructed the privilege against self-incrimination in a way that often encourages the accused to rely entirely upon the intermediation of counsel and say nothing in his own defense. But in the period before the accused had counsel, there could be no practical distinction between his roles as defender and as witness. The accused spoke continually at the trial, replying to prosecution witnesses and giving his own version of the events.

84. Langbein, supra note 83, at 277.

85. F. D. MacKinnon, The Law and the Lawyers, in 2 A. S. Turberville, ed., Johnson's England 287, 307 (Oxford: Clarendon Press, 1933) (referring to R. v. Hardy, 24 St. Tr. 199 (1794)).

86. United States, Administrative Office of the United States Courts, 1976 Annual Report of the Director, app. at p. I-41 table C9 (Washington, D.C.: Administrative Office of the United States Courts, 1976).

87. The figure for Los Angeles appears in San Francisco Committee on Crime, A Report on the Criminal Courts of San Francisco, Part I: The Superior Court Backlog-Consequences and Remedies 1 (1970). See Langbein, supra note 16, at $10 \mathrm{n} .18$, for further discussion of this and comparable figures.

88. The following account is based on Langbein, supra note 83.

89. New York Times, March 12, 1971, p. 43, summarized in Yale Kamisar, Wayne R. LaFave, \& Jerold H. Israel, Modern Criminal Procedure 1329 (4th ed. St. Paul, Minn.: West Publishing Co., 1974). 
4. The presentation of evidence and the cross-examination of witnesses and accused took place in a fashion that was businesslike but lacked the time-consuming stiffness of a modern adversary trial, which has strict rules of sequence and phase preclusion. The trial judge superintended this "altercation" 90 of witnesses and accused, occasionally examining or cross-examining, and he exercised a broad power to comment upon the evidence.

5. The common law of evidence, which has injected such vast complexity into modern criminal trials, was virtually nonexistent as late as the middle decades of the eighteenth century. The trial judge had an alternative system of jury control that was both swifter and surer than the subsequent resort to rules of admissibility and exclusion. He had unrestricted powers of comment on the merits of criminal cases; he could reject a verdict that displeased him and require the jury to deliberate further; indeed, until 1670 he had been able to fine a jury that persisted in acquitting against his wishes.

6. In an age before professional police and prosecutors, the problems of controlling such officers and protecting the accused from abuse of their powers lay wholly in the future. The remarkable American exercise of attempting to substitute exclusionary rules of evidence for a direct system of discipline was not yet operating to protract the criminal process.

7. There was as yet virtually no appeal in criminal cases. Accordingly, the familiar modern machinations of counsel directed to provoking and preserving error for appeal were unknown.

The criminal justice that was administered in this system of summary jury trial was rough indeed. We are not surprised, therefore, that pressures developed over the subsequent two centuries to modify jury trial in order to increase the level of protection against mistaken conviction. What historical research has not yet explained is why these pressures led in the Anglo-American procedure to the law of evidence and the lawyerization of the trial, reforms that ultimately made jury trial so complicated and time-consuming that it became unworkable as a routine dispositive procedure. Similar pressures for safeguard were felt on the Continent in the same period, but they led to reforms, including the development of the mixed court, that preserved the institution of trial.91

If the developments that have rendered jury trial impractical had happened in a concentrated and visible fashion, Americans might have had occasion to give proper consideration to devising alternatives capable of preserving some of the jury policies. What actually occurred over the last

90. The famous term of Sir Thomas Smith, De Republica Anglorum 80 (London 1583).

91. This paragraph is derived from John H. Langbein, Torture and Plea Bargaining, The Public Interest, Winter 1980, at 49-50. 
century was a gradual and somewhat stealthy growth of bench trial and plea bargaining. Only because this departure from our supposed constitutional principles is now so familiar to us do we fail to appreciate how astounding the phenomenon really is (and how bizarre it appears to foreigners who encounter it afresh). A substitute criminal procedural system, wholly devoid of lay participation, has displaced jury trial in practice, even while the Supreme Court has been celebrating the virtues of the jury and purporting to extend the constitutional jury guarantee to the states.

By narrowing the gap between our jury entitlement and our nonjury system, the Continental mixed court would in principle be a manifestly superior alternative to bench trial and especially to plea bargaining. If, as I believe, the day must come when the level of dissatisfaction with the plea bargaining system becomes intolerable, Americans may finally undertake the search for a principled alternative to adversary jury trial. The mixed-court system that I have described in operation in West Germany provides full adjudication with lay participation in every case of serious crime. Because the mixed-court system is so imbued with the ideals that underlie our constitutional jury guarantee, it deserves to be the subject of some experimentation and adaptation in the United States. 
HeinOnline -- 1981 Am. B. Found. Res. J. 2201981 